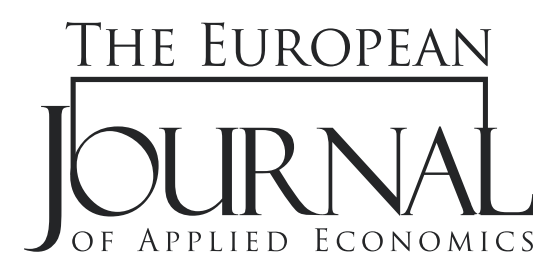

EJAE 2020, 17(1): $67-79$

ISSN 2406-2588

UDK: 338.45:663.4(73)

339.13.012.432

DOI: $10.5937 /$ EJAE17-22500

Original paper/Originalni naučni rad

\title{
IS THERE MARKET POWER IN THE U.S. BREWING INDUSTRY?
}

\section{Sanjib Bhuyan}

Department of Agricultural, Food and Resource Economics, Rutgers University - New Jersey,

New Brunswick, USA

\begin{abstract}
:
Increased consolidation in the U.S. brewing industry has raised legitimate concern about brewing firms' ability to exert market power over the downstream. Using structural models of oligopoly behavior, this research estimates the market power in the U.S. beer (manufacturing) industry over a 30-year period, during which the sector experienced a rapid increase in concentration and the demise of many small firms. The results show that the beer market is price-sensitive, and that both distilled spirits and carbonated soft drinks were substitutes for beer. While we were unable to detect the impact of the labor and material costs for the price of beer, we found that the federal tax on beer increased beer prices. Our results indicate that while there was some indication of market power, U.S. brewers did not exert oligopoly power over downstream firms (distributors and retailers).
\end{abstract}

\section{Article info:}

Received: July 12, 2019

Correction: September 19, 2019

Accepted: September 27, 2019

\section{Keywords:}

U.S. brewing industry, market power,

NEIO.

\section{JEL classification:}

L13, D43

\section{INTRODUCTION}

The United States is one of the largest producers of beer in the world, and in 2016 it ranked second amongst the countries worldwide in beer production with an amount of about 221 million hectoliters (Conway, 2018). The U.S. ranked $11^{\text {th }}$ in worldwide beer consumption in 2018 with per capita consumption at 74.66 liters/year (Statistica, 2019). ${ }^{1}$ According to the Beverage Information Group (2018), light beer ${ }^{2}$ is the most commonly purchased style of beer in the U.S., accounting for 43.5 percent of total sales in 2017. Beer continues to dominate the alcoholic beverage market in the U.S. despite losing its share of the market for alcoholic beverages over last couple of decades, mostly to spirits and, to a lesser extent, to wine. The market share of beer in the alcoholic beverage market in the United States

1 The Czech Republic topped the list with an annual per capita beer consumption of $137.3 \mathrm{lt}$.

2 Beer with reduced alcohol content or reduced calorie content is called 'light beer.' 
fell from 55.5\% in 2000 to $45.5 \%$ in 2018 (DISCUS, 2019). Conway (2018) reported that the U.S. beer industry sold $\$ 34.17$ billion worth of beer in 2016 , mostly through convenience stores and grocery stores. The economic downturn that began in 2007 led U.S. consumers to purchasing cheap beer; nonetheless, the popularity of premium and craft beers continued to rise, and is expected to benefit the industry (IBISWorld, 2012).

Beer is bulky because it is made up of mostly water and, therefore, to reduce the costs of production and transportation, efforts to achieve economies of scale is a commonly pursued strategy in the industry. As a result, the consolidation of breweries in the United States that started in the 1970s with the purchase of Miller Brewing by Phillip Morris continues today. Although there were reportedly over 5,600 breweries in the United States in 2017, over 95\% of them were producing fewer than 15,000 barrels ( 1 barrel $=31$ US gallons) a year, i.e., these breweries were very small (NBWA, 2019). The Boston Beer Company, producer of Samuel Adams brand, and the largest craft beer brewing company in the U.S., supplies only about $2.3 \%$ of the beer market (IBISWorld, 2012). As of 2018, the top four brewers, namely Anheuser-Busch InBev (AB InBev), MillerCoors, Constellation, and Heineken USA control almost 78\% of the market (NBWA, 2019). Not surprisingly, the leading beer brands in the United States are owned by these top firms (Figure 1). It is clear that despite the recent rapid growth of domestic craft beer and foreign imports, the U.S. brewing sector continues to be dominated by macro breweries, such as $\mathrm{AB}$ InBev.

Figure 1 - Market share of the leading domestic beer brands in the United States in 2017

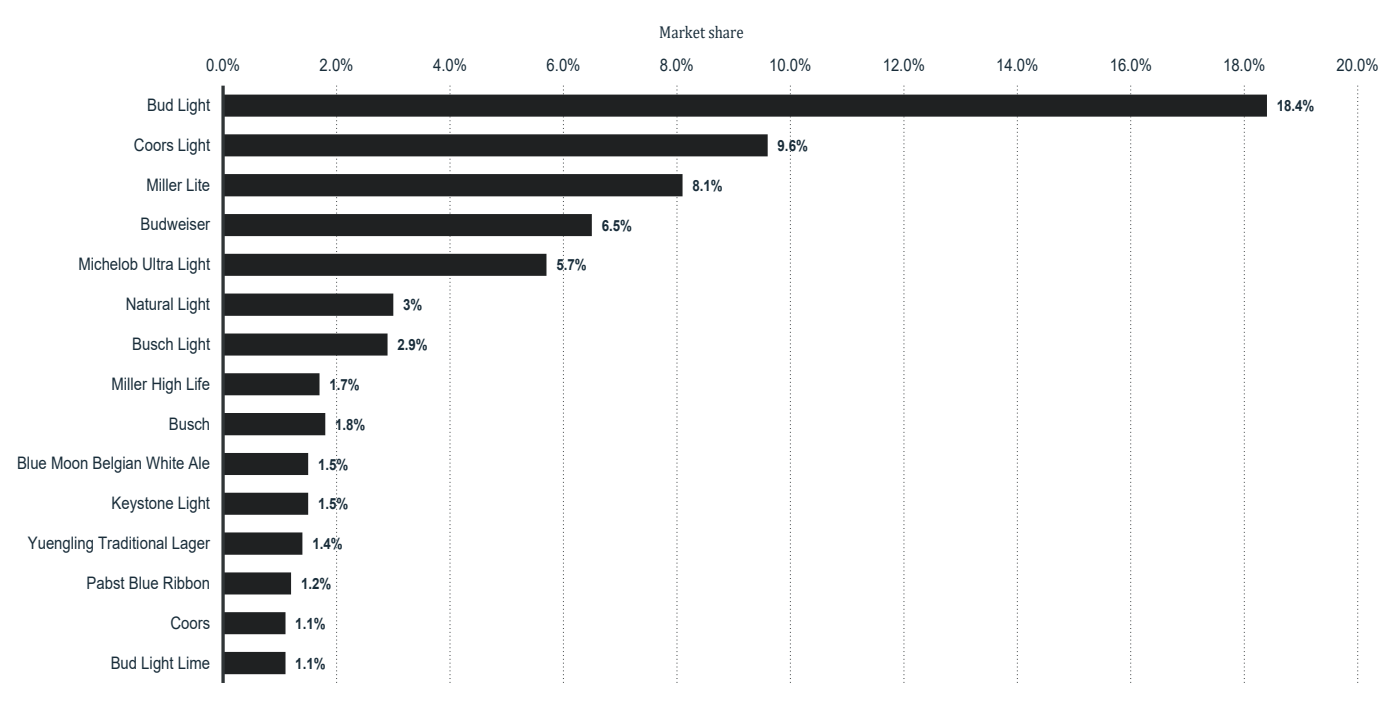

Note: United States; 52 weeks ended January 22, 2017

Source: Grocery Headquarters, 2019

After the 2008 megamergers of Anheuser-Busch with Belgium's InBev, and Coors with SABMiller, only two major players remained in the U.S. brewing market: AB InBev and MillerCoors, respectively, controlling $42.1 \%$ and $33.2 \%$ of the U.S. brewing market (IBISWorld, 2012). Bhuyan and McCafferty (2013) argue that, although some researchers (e.g., Elzinga and Swisher, 2011) contest the argument that increased consolidations in the U.S. brewing industry led to a more concentrated market structure and raised the possibility of market power in the industry, the increasing concentration in the U.S brewing industry raised public policy concerns, and such concerns were at the heart of a decision by the U.S. 
Department of Justice (DOJ) to block the proposed merger between AB InBev and Mexico's Groupo Modelo. Commenting on this particular action by the DOJ, the Wall Street Journal (WSJ, 2013) reported that the DOJ was concerned about the AB InBev potentially controlling over $46 \%$ of the market share and potentially raising prices in the post-merger period.

Given the structural changes that occurred in the U.S. beer industry over the last few decades that led to its current highly concentrated nature, one of the questions that surfaces is the following: is there market power in the U.S. brewing industry? We are not proposing to examine the relationship between market concentration and industry profitability here, but to quantitatively test for market power in the U.S. beer industry using the well-established New Empirical Industrial Organization (NEIO) approach. ${ }^{3}$ The NEIO approach uses oligopoly theory to develop market models that allow explicit testing of a hypothesis regarding market power, and we hypothesize that there is no market power in the U.S. brewing industry. For this study, we use the 1977-2006 period during which the U.S. brewing industry experienced a rapid increase in concentration, as well as a severe price war in the early to mid-1980's, leading to the demise of many small firms. This research contributes to the economics literature that focuses on the U.S. brewing industry.

\section{PREVIOUS RESEARCH IN BRIEF}

As Bhuyan and McCafferty (2013) argued, increasing concentration in the U.S brewing industry has raised public policy concerns concerning the potential impact of industry consolidation on market power. They also argue that industry concentration is of importance in industry analysis because a change in concentration can have a significant effect on the behavior of firms and the economic performance of the market. As mentioned earlier, it was perhaps not surprising that the DOJ blocked the proposed merger between AB InBev and Mexico's Grupo Modelo.

In an earlier study, Tremblay and Tremblay (1995) examined competition in the U.S. brewing industry, and rejected the hypothesis that firms were price takers over the 1950-1988 period. However, they argue that the conjectural variation estimate was close to a Bertrand oligopoly, and that the level of market power was modest. They also rejected the hypothesis that large firms and high concentration resulted in market power. They found no significance in increasing concentration resulted in an increase in the price of beer. They also found that growth in one period resulted in a negative effect on price. This follows Demsetz's (1973) argument that superior firms may be more efficient and able to charge lower prices. Tremblay and Tremblay's (1995) most significant finding is the effect of advertising on its output price; they found that advertising had a significant impact on increasing rivals' prices.

In a more recent study that uses a NEIO model to estimate demand and supply functions simultaneously, Denney et al. (2002) found that there is negligible market power in the U.S. beer industry. Gallet and Euzent (2002) looked at how the business cycle affected competition in the brewing industry. They found that competition was higher during periods of high demand and expectations about future profits were low.

Iwasaki, Seldon, and Tremblay (2008) used the SCP (structure conduct performance) approach to estimate a system of equations to explain industry concentration, advertising intensity, and profitability in the U.S. brewing industry. Their findings reveal that performance, as measured by the PCM, increases with concentration. They also found that concentration increased with advertising and scale efficiency.

3 Since its inception in the early 1980s, some variation of the NEIO approach has been used by researchers to measure and test for industry market power. Unlike the original model proposed by Appelbaum (1982), such variations may include a priori assumptions about non-competitive behavior $(\mathrm{P}>\mathrm{MC})$, such as in the recently proposed Stochastic Frontier (SF) approach by Kumbhakar, Baardsen, and Lien (2012). In this research, there is no a priori assumption about non-competitive behavior in the U.S. brewing industry. 
Using a brand-level data set, Rojas (2008) evaluated different pricing models in the U.S. beer industry. This study was designed to reflect and test forms of market leadership commonly reported for this industry. According to Rojas, the Stackelberg leadership was a somewhat better predictor of firm behavior. Rojas' findings are similar to earlier findings of Nevo (2001), who focused on the RTE (ready to eat) cereal market, and Slade (2004), who focused on the U.K. brewing sector; both researchers reject the notion of full collusion in their respective research. Using a nonparametric approach, Pipoblabanan (2008) rejected the hypothesis that firm behavior in the U.S. brewing industry reflects cartel behavior. However, one of the interesting findings of this study was that there was a positive correlation between concentration and the degree of market power.

Gokhale and Tremblay (2011) followed up earlier work by Tremblay and Tremblay (2005), and examined the changes in market power from 1987 to 2009 using a traditional NEIO approach. They also looked at the relationship between concentration and market power. Their results show that, during that time period, there was an increase in competition and a fall in market power in the U.S. brewing industry. They attribute this to a price war fought between U.S. brewing firms in the 1970s and 1980s to gain market share by keeping prices low.

The research presented here complements this strand of literature that focuses on market power in the U.S. brewing industry, and thus contributes to the relevant literature.

\section{DATA AND METHODS}

\section{Secondary Data}

This study covers the period of 1977-2006, which witnessed a rapid increase in consolidation, ugly beer price wars, and the demise of many small breweries in the United States. As per the industry standard, the price of beer (wholesale price) is measured in 31-gallon barrels ( 1 gal=3.785 liters) and was normalized (deflated) by the beer price index. The beer price index was obtained from various issues of the 'PPI Detailed Report,' which is published by the U.S. Department of Labor. In terms of the input prices, the payroll price and price of materials were deflated by the employment cost index and agricultural grain price index, respectively. ${ }^{4}$

Disposable income was deflated with the Consumer Price Index (CPI, courtesy the Bureau of Labor Statistics, 2012) and the federal beer tax (courtesy U.S. Brewers Association, 2011) was deflated using the Producer Price Index (PPI, courtesy the Bureau of Labor Statistics, 2012). ${ }^{5}$

Table 1 presents data descriptions and sources, and Table 2 presents the descriptive statistics. The price data used in the analysis is normalized to 1984 dollars.

\section{Conceptual Model ${ }^{6}$}

We follow Bresnahan (1989) to develop a standard NEIO model to estimate market power in the U.S. brewing industry where brewing firms sell beer to a retailing sector for sale to final consumers. We hypothesize that brewing firms exercise market power (oligopoly power) over the retail sector which is assumed to be price-takers.

4 The agricultural grain price index is used because the main materials in the production of beer are malt, corn, and rice (U.S Brewers Association, 2011).

5 The PPI for the brewing industry was used because brewers bear the cost of the per barrel tax.

6 For an extensive and more informative presentation on NEIO, see Bresnahan, 1989. 
We specify a profit maximizing firm i, maximizing its profit, $\pi_{i}$, with respect to its own quantity, $q_{i}$, at a cost $C_{i}\left(w, q_{i}\right)$, where cost for the firm $i$ is a function of inputs $(w)$ and the quantity it produces. The price that firm $i$ faces is $\mathrm{P}$ which is a function of industry supply $Q\left(\sum_{i=1}^{n} q_{i}\right)$ and its own supply, $q_{i}$. Then firm $i$ 's objective function is given by:

$$
\pi_{i}(w, q)=P\left(Q, q_{i}\right) q_{i}-C\left(w, q_{i}\right)
$$

Profit maximizing yields:

$$
\begin{aligned}
& \frac{\partial \pi_{i}}{\partial q_{i}}=P+\left[\frac{\partial P}{\partial Q}+\frac{\partial P}{\partial Q} \frac{\partial Q}{\partial q_{i}}\right] q_{i}-\frac{\partial C\left(q_{i}\right)}{\partial q_{i}} \\
& \frac{\partial P}{\partial Q}\left[1+\theta_{i}\right] q_{i}+P-\frac{\partial C\left(q_{i}\right)}{\partial q_{i}}=0 \\
& P=\frac{\partial C\left(q_{i}\right)}{\partial q_{i}}-\frac{\partial P}{\partial Q}\left[1+\theta_{i}\right] q_{i}
\end{aligned}
$$

One should note that the above model is a static one-shot game and provides only one-shot game solutions. It is unable to provide information on situations involving repeated games or dynamic firm behavior. ${ }^{7}$ We, therefore, use the term $\frac{\partial Q}{\partial q_{i}}$ as a behavioral parameter describing market conduct, rather than as an indicator of expectations by rival firms. This parameter is commonly referred to as the "conjectural variation" parameter. As common in similar studies, the behavioral parameter $\frac{\partial Q}{\partial q_{i}}$ is able to describe whether market power is present (or absent), and is represented by $\theta_{i}$ in Eq. 4 .

As presented initially in Applebaum (1982) and later followed by researchers using industry-level data, in the absence of firm level data, it is possible to aggregate Eq. 4 across firms and find a market power measure that characterizes the industry market power at the aggregate level (Bhuyan, 2013). Bhuyan (2014) argues that this is a standard assumption in this type of model stemming from the scarcity of firm-level data and the need to allow for consistent aggregation over firms. However, Bresnahan (1989) has argued that the marginal costs of firms are likely to vary in equilibrium when market power exists. The suggested alternative, as presented in Bhuyan (2014), is to interpret the aggregate conjectural variation estimated at the industry level as average industry conduct, and the market power parameter as the average industry mark-up, as in Cowling and Waterson (1976). Therefore, if one takes $M C$ to be the average marginal cost of the industry and $\theta$ to be the average conjectural variation (or average conduct parameter), then the industrywide counterpart to Eq. 4 will become the following estimable equation, where the measure of market power parameter in the industry is: $\omega=-\frac{\partial P}{\partial Q}[1+\theta]$ :

$$
P=\overline{M C}+\omega Q
$$

The relationship between the market power parameter $(\omega)$ and the conjectural variation parameter $(\theta)$ is given by $\omega=-\frac{\partial P}{\partial Q}[1+\theta]$, and it shows how differing levels of the conjectural variation parameter can affect market power and consequently price (Bhuyan, 2014). In a competitive behavior setting, $\theta=-1$

7 There have been attempts to allow the conduct parameter (here $\theta$ ) vary over time (e.g., $\theta=f($ time $)$ ) to capture the dynamic nature of an industry, e.g., Dixon and Somma (2003). However, it has been found that on average, the estimated "dynamic" $\theta$ is equivalent to an estimated static $\theta$. 
and this implies $\omega=0$. On the other hand, a Cournot behavior implies that $\theta=0$ and, $\omega=-\frac{\partial P}{\partial Q}$ whereas a cartel behavior implies that $\theta=1-N$ and, $\omega=-\left(\frac{\partial P}{\partial Q}\right) N$ where $N$ is the number of firms in the market.

Also note that if $\theta \geq-1$ and if $\frac{\partial P}{\partial Q} \leq 0$ then this means $\omega \neq 0$.

The estimation of the structural equation, Eq. 5, requires two equations to be solved simultaneously; one of these equations is a demand function for the beer industry and the other is the cost function for the beer industry (see Bhuyan, 2014, for a similar treatment). Once these equations are established, the market power parameter can be estimated by solving both equations simultaneously. Note from an earlier discussion that our hypothesis is $\omega=0$, that is, there is no market power in the U.S. brewing industry; the alternate hypothesis is that the re is market power $\omega=\geq 0$, and the estimated market power parameter $(\hat{\omega})$ is positive and significant.

\section{Model Estimation}

This section describes the construction of a simultaneous equation model to estimate the proposed model of testing for market power in the U.S. brewing industry. This model is based on the theoretically derived behavioral or conjectural variation model represented by Eq. 5 . In order to estimate the market power variable, $\omega$, (in Eq.5), we need both the market demand function and the industry supply relations. To obtain the total cost function (needed to determine the supply function), we follow Denney et al. (2002) and Pipoblabanan (2008), and use a Generalized Leontief functional cost function. ${ }^{8}$ We define $w_{t}^{L}$ as the price of payroll, $w_{t}^{M}$ as the price of materials, $K_{t}$ as the quantity of capital, and $\operatorname{tax}_{t}^{\text {scd }}$ as the federal tax charged in the production of a barrel of beer. Then the total cost function of the U.S. brewing industry is given by:

$$
C_{t}=\beta_{o}+\beta_{1} w_{t}^{L}+\beta_{2} w_{t}^{M}+\beta_{3}\left(w_{t}^{L} w_{t}^{M}\right)^{\frac{1}{2}}+\beta_{4} \operatorname{tax}_{t}^{\text {fed }}
$$

To estimate Eq. 5, we also need a demand function representing the demand for beer in the United States. As found in similar studies, a semi-log demand functional form is assumed here to represent beer demand in the U.S. where $P_{t}$ is the price of beer, Price ${ }^{\text {cola }}$ is a price index for carbonated drinks, Price ${ }^{\text {spirits }}$ is a price index for spirits, Inc is disposable income, and $\varepsilon_{t}$ is an error term. Then the demand for the U.S. brewing industry is presented as a semi-log function:

$$
Q_{t}=a_{0}+a_{1} \ln P_{t}+a_{2} \ln \operatorname{Price}_{t}^{\text {Sprits }}+a_{3} \ln \operatorname{Price}_{t}^{\text {cola }}+a_{4} \ln \operatorname{Inc} c_{t}+\varepsilon_{t}
$$

Estimation of Eq. 5 also requires marginal cost function and following earlier studies, we use Eq. 6 as a proxy. The demand function in Eq. 7 is used to represent the " $Q$ " in Eq. 5. We then substitute Eq. 6 and Eq. 7 onto the right-hand side of Eq. 5 to obtain Eq. 8, or the empirical model we need to estimate to determine existence of market power in the U.S. brewing industry:

$$
P_{t}=\beta_{o}+\beta_{1} w_{t}^{L}+\beta_{2} w_{t}^{M}+\beta_{3}\left(w_{t}^{L} w_{t}^{M}\right)^{\frac{1}{2}}+\beta_{4} K_{t}+\beta_{s} t a x_{t}^{\text {fed }}+\omega Q_{t}+\gamma_{t}
$$

To address the endogeneity issue in Eq. 8 (because quantity and price are contained in both Eq. 7 and Eq. 8), we simultaneously estimate Eq. 7 and Eq. 8 to determine the market power parameter $\omega$.

8 The generalized Leontief function has primarily been used in empirical studies for cost functions in an industry with a single output. Here we consider the main product of the U.S. brewing industry as a single output, beer. Gallet and Euzet (2002) and Xia and Buccola (2003) also find the Generalized Lenotief Function is an appropriate form in estimating the cost structure of the U.S. brewing industry. 
We used PROC MODEL in SAS version 9.4. Information on the variables used, data set, and the SAS program codes used to estimate equations (7) and (8) are provided in the appendix.

\section{Discussion of Results}

Estimated coefficients of the simultaneous equations are reported in Table 3 along with their respective $t$-statistics and a measure of the overall model performance. Starting with the demand equation (Eq. 7), the sign on the price of beer is negative, as expected, (suggesting a downward slopping demand curve) and statistically significant.

Although the estimated parameter is not equal to own price elasticity of beer (due to the semi-log form of the demand function), the estimated beer price coefficient indicates that the own price elasticity of beer demand in the U.S. is negative; this result shows the price sensitivity of beer consumers in the country.

We know from an earlier discussion that beer has been losing its market share in the U.S. to spirits. Our results empirically confirm that beer competed with spirits in the U.S., as evident from the positive and significant coefficient for price of spirits variable, indicating the substitutability of spirits and beer. That is, as the price of spirits (beer) goes up, the quantity demanded for beer (spirits) goes up too. According to the Washington-based Distilled Spirits Council, the market share of distilled spirits in the U.S. alcoholic beverage market grew from $28.7 \%$ in 2000 to $37.3 \%$ in 2018 , increasing its share mostly at the cost of beer (DISCUS, 2019). Beer also competes with non-alcoholic carbonated drinks in the U.S. Although statistically not significant, the estimated coefficient for the carbonated soft drink price variable was positive, depicting the substitutability of carbonated drinks with beer.

Income is expected to have a positive impact on the demand for any normal good. Table 3 shows that the estimated coefficient of disposable income was positive (but statistically not significant), which indicates that beer is a normal good; this is consistent with the finding of Denney et al. (2002), who also found that beer consumption grows with income growth; this is because beer is an affordable luxury item.

We now turn our attention to the supply relation results in column four of Table 3 . The signs on the coefficients for both labor cost and material cost variables were negative and statistically not significant. We expected both variables to have a positive and significant impact on beer price, because rising labor and material costs should lead to a rise in beer prices. Similarly, decreasing labor and material costs should, in the absence of market power, pass on the cost savings to consumers in terms of lower beer price. We were unable to support our expectations because the coefficients of these cost variables were statistically insignificant. On the other hand, as one would expect, taxation leads to higher prices - the sign on the coefficient of the federal taxation variable is positive and statistically significant. This indicates that a dollar increase in the Federal beer tax per barrel will have a thirteen-fold increase in beer prices. ${ }^{9}$ Finally, the parameter estimate on capital stock is negative as expected (not statistically significant). Higher capital stock implies firms investing in better technology, which is expected to lower the cost of beer production, leading ultimately to lower beer prices - a sign of firms becoming more efficient through improved technology and able to compete in a price-sensitive market.

Finally, results in Table 3 show that market power parameter $(\omega)$ is positive but not statistically significant, that is, we were unable to reject the null hypothesis that there is no market power in the U.S. brewing industry, i.e., $(\omega=0)$ Although statistically indifferentiable, the positive sign of the parameter $(\omega)$ indicates the existence of market power in the U.S. beer industry.

9 Although the impact of the federal tax seems excessive, we left that debate for another time, given that the focus of this study lies elsewhere. 
Given the continued consolidation that led to increasing industry concentration in the U.S. brewing industry, our finding was unexpected but was not surprising. It is not surprising because our finding is similar to Tremblay and Tremblay (1995), who also detect the existence of some statistically indifferentiable market power in the U.S. brewing industry. Given the impact of the capital stock on beer prices (negative, albeit statistically insignificant), our finding may provide a weak support to Demsetz's (1973) proposition that efficient firms are able to grow over time, resulting in larger and more efficient firms leading to a rise in market concentration, but not necessarily market power. In the U.S. brewing industry, such cost-efficient firms with large market shares would be the macro breweries, such as $\mathrm{AB}$ InBev and MillerCoors.

\section{CONCLUSION}

Increased consolidation in the U.S. brewing industry has left the industry with the top four firms controlling almost $78 \%$ of the beer market in the country. A legitimate concern that arises out of such continued consolidation is whether there is market power in this industry. Using structural models of oligopoly behavior, we estimate conduct parameters that identify a degree of market power in this industry over the 1977-2006 period, during which the sector experienced a rapid increase in concentration and the demise of many small firms.

We find that the U.S. beer market is price-sensitive, and both distilled spirits and carbonated soft drinks were competitors (or substitutes to beer). Given distilled spirits are gaining ground on beer over the last few years and beer consumers are sensitive to price, it may require innovations in both the production and marketing of beer to regain lost ground in the U.S. alcoholic beverages market. While we were unable to detect the impact of labor and material costs on the price of beer, we were not surprised to find that excise tax (federal tax on alcohol) increased beer price.

In terms of the focus of this article, our empirical results indicate that although we find evidence of the existence of market power in the U.S. beer industry, we are unable to refute (statistically) the hypothesis that there is no market power in this industry. In line with an earlier study by Tremblay and Tremblay (1995), we conclude that while there is some indication of market power, there is not enough statistically supported evidence to conclude that there is market power in the U.S. brewing industry, i.e., brewers do not exert oligopoly power over downstream firms (distributors and retailers). Although none of the coefficients of variables representing cost and technology were statistically significant, their directions indicate that lower cost and better technology may allow efficient firms to lower beer prices and gain market share (and thereby leading to even higher concentration).

In terms of future research agenda, the research presented here could be extended beyond the year 2006 to include more recent data; variations of the NEIO model, such as the SF approach, could also be utilized, albeit with a priori assumptions about market competitiveness in the U.S. brewing industry. 


\section{REFERENCES}

Appelbaum, E. (1982). "The estimation of the degree of oligopoly power." Journal of Econometrics 19(2-3): 287-299.

Bartelsman, E. J., Becker, R.A., and W.B. Gray. (2005). "NBER-CES Manufacturing Industry Database. National Bureau of Economic Research technical working paper 205.

Beverage Information Group. (2018). "Beer consumption in the United States in 2017, by category (in 1,000 2.25-gallon cases)." Chart. July 11, 2018. Statista. Accessed July 10, 2019. https://www.statista.com/statistics/466652/us-consumption-of-beer-by-category/

Bhuyan, S. (2014). "Visiting an Old Battleground in Empirical Industrial Organization: SCP vs. NEIO." Applied Economics Letters, 21 (11): 751-754.

Bhuyan, S. and M. McCafferty. (2013). "U.S. brewing Industry Profitability: A Simultaneous Determination of Structure, Conduct, and Performance." Jr. of Agricultural \& Food Industrial Organization, 11(1): 139-150.

Bresnahan, T. (1989). "Empirical methods for industries with market power." In R. Schmalensee and R. Willig, eds. Handbook of Industrial Organization, Volume II, Elsevier Science. The Netherlands: Publishers B.V., pp. 1011-1057.

Conway, J. (2018). “Global Beer Industry - Statistics \& Facts." Accessed July 10, 2019. https://www.statista.com/ topics/1654/beer-production-and-distribution/

Cowling, K. and M. Waterson. (1976). "Price-cost margins and market structure." Econometrica 43: 267-274.

Demsetz, H. (1973). "Industry Structure, Market Rivalry and Public Policy." Journal of Law and Economics 16:1-9.

Denney, D., B. Lee, D.W. Noh, and V.J. Tremblay. (2002). "Excise taxes and imperfect competition in the U.S. brewing industry." Working Paper, Department of Economics, Oregon State University.

DISCUS. (2019). "Sales market share of the United States alcohol industry from 2000 to 2018, by beverage." Chart. February 12, 2019. Statista. Accessed July 10, 2019. https://www.statista.com/statistics/233699/marketshare-revenue-of-the-us-alcohol-industry-by-beverage/

Elzinga, K.G., and Swisher, A.W. (2011). "Developments in US Merger Policy: The Beer Industry as Lens." In Johan F.M. Swinnen (ed.) The Economics of Beer. Pp. 196-212. New York, NY: Oxford University Press.

Gallet, C.A. and Euzent, P.J. (2002). “The Business Cycle and Competition in the U.S. Brewing Industry.” Journal of Applied Business Research 18(2): 89-96.

Gokhale, J. and V.J. Tremblay. (2011). "Competition and Price Wars in the U.S. Brewing Industry." Working Paper, Department of Economics, Oregon State University.

Grocery Headquarters. (2019). "Market share of the leading domestic beer brands in the United States in 2017." Chart. April 1, 2017. Statista. Accessed July 10, 2019. https://www.statista.com/statistics/586533/marketshare-domestic-beer-brands-united-states/

IBISWorld. (2012). "Breweries in the US.” IBISWorld Industry Report 31212, November 2012.

Iwasaki, N., B.J. Seldon, and V.J. Tremblay. (2008). "Brewing Wars of Attrition for Profit and Concentration," Review of Industrial Organization 33:263-279.

Kumbhakar, S.C., Baardsen, S., and Lien, G. (2012). "A new method for estimating market power with an application to Norwegian sawmilling." Review of Industrial Organization 40(2):109-129.

National Beer Wholesalers Association (NBWA). (2019). "Industry Fast Facts.” Accessed July 8, 2019. https:// www.nbwa.org/resources/industry-fast-facts.

Nevo, A. (2001). "Measuring Market Power in the Ready-to-Eat Cereal Industry." Econometrica 69: 307-342.

Pepall, L., D. Richards, and G. Normam. (2002). Industrial Organization: Contemporary Theory and Practice. New York: South-Western College Publishing.

Pipoblabanan C. (2008). "Essays on Parametric and Nonparametric Estimation of Market Structure and Tax Incidence in the U.S. Brewing Industry." Ph.D. Thesis, Oregon State University.

Rojas, C. (2008). “Price Competition in U.S. Brewing.” Journal of Industrial Economics 61:1-31.

Slade, M. (2004). "Market Power and Joint Dominance in U.K. Brewing." Journal of Industrial Economics 52: 133-163. 
Statistica. (2019). "Per-capita volume sales in the beer market worldwide, by country in 2018 (in liters)." Chart. January 3, 2019. Statista. Accessed July 10, 2019. https://www.statista.com/forecasts/758742/per-capitavolume-sales-in-the-beer-market-worldwide-by-country

Tremblay, V. J. and C.H. Tremblay. (1995). “Advertising, price, and welfare: evidence from the US brewing industry." Southern Economic Journal 62(2): 367-381

Tremblay, V.J. and C.H. Tremblay. (2005). The US Brewing Industry: Data and Economic Analysis. Cambridge, MA: MIT Press. U.S. Brewers Association. (2011). Brewers Almanac, various issues, Brewers Association, United States: Washington, DC.

U.S. Department of Commerce. (2013). Manufacturing: Summary Series: General Summary: Industry Statistics for Industry Groups and Industries: 2007. Bureau of the Census. Available at https://www.census.gov/ data/tables/2007/econ/census/manufacturing-reports.html. Accessed on July 10, 2019.

U.S. Department of Commerce. (2012). Bureau of the Census. Annual Survey of Manufacturers various issues, Washington DC.

(2011). Bureau of Economic Analysis. National Income in the United States, various issues, Washington, DC.

U.S. Department of Labor, Bureau of Labor Statistics. (2012). CPI Detailed Report, various issues, Washington DC.

Wall Street Journal (WSJ), (2013). “U.S. Sues to Block Big Beer Merger.” written by Brent Kendall and Valerie Bauerlein. January 31, Thursday.

Xia, Y., and S.B. Buccola. (2003). "Factor Use and Productivity Change in Alcoholic Beverage Industries." Southern Economic Journal 70(1): 93-109.

Tables

Table 1: Variable descriptions

\begin{tabular}{lll}
\hline Variable & Description & Source \\
\hline $\boldsymbol{Q}_{t}$ & $\begin{array}{l}\text { Quantity of beer consumed measure in mil- } \\
\text { lions of 31-gallon barrels }\end{array}$ & U.S. Brewers Assoc. (2011) \\
\hline $\boldsymbol{P} \boldsymbol{t}$ & Price per 31-gallon barrel (Base=1984) & U.S. Brewers Assoc. (2011) \\
\hline $\boldsymbol{P r i c e}^{\text {Spirits }}$ & Price index of spirits (Base=1984) & U.S. Department of Labor (2012) \\
\hline $\boldsymbol{P r i c e}^{\text {Cols }}$ & $\begin{array}{l}\text { Price index for carbonated drinks } \\
\text { (Base=1984) }\end{array}$ & U.S. Department of Labor (2012) \\
\hline $\boldsymbol{I n \boldsymbol { c t }}$ & Per capita Disposable income in 1984 dollars. & U.S. Department of Commerce (2011). \\
\hline $\boldsymbol{w}_{t}^{L}$ & Payroll price per barrel in 1984 dollars & Bartelsman, Becker, and Gray (2005) \\
\hline $\boldsymbol{w}_{\boldsymbol{t}}^{M}$ & Material price per barrel in 1984 dollars & Bartelsman, Becker, and Gray (2005) \\
\hline $\boldsymbol{K}_{\boldsymbol{t}}$ & Real Capital Stock in 1984 dollars & Bartelsman, Becker, and Gray (2005) \\
\hline $\boldsymbol{t a x}_{\boldsymbol{t}}^{\text {fed }}$ & $\begin{array}{l}\text { Federal excise tax rate (dollars per barrel) } \\
\text { in 1984 dollars }\end{array}$ & U.S. Brewers Assoc. (2011) \\
\hline
\end{tabular}

Table 2: Descriptive statistics of variables

\begin{tabular}{lrrrr}
\hline Variable & Mean & \multicolumn{2}{c}{ Std. } & \multicolumn{2}{c}{ Maximum } \\
\hline $\boldsymbol{Q}_{\boldsymbol{t}}$ & 193.190 & 9.847 & 177.813 & 213.094 \\
\hline $\boldsymbol{P t}$ & 75.327 & 7.870 & 60.875 & 88.1439 \\
\hline Price $^{\text {Spirits }}$ & 98.697 & 5.300 & 88.059 & 111.667 \\
\hline Price $^{\text {Cols }}$ & 83.035 & 12.704 & 67.940 & 107.265 \\
\hline $\boldsymbol{I n c t}^{\boldsymbol{L}}$ & 16870.139 & 3620.729 & 10476.088 & 21835.505 \\
\hline $\boldsymbol{w}_{\boldsymbol{t}}$ & 5.385 & 1.609 & 2.568 & 8.390 \\
\hline $\boldsymbol{w}_{\boldsymbol{t}}$ & 34.220 & 3.603 & 23.545 & 39.706 \\
\hline $\boldsymbol{K}_{\boldsymbol{t}}$ & 14535.476 & 2939.940 & 11187.494 & 20767.0266 \\
\hline $\boldsymbol{t a x}_{\boldsymbol{t}}^{\text {fed }}$ & 13.144 & 3.224 & 8.478 & 17.622 \\
\hline
\end{tabular}


Table 3: Estimation results

\begin{tabular}{|c|c|c|c|}
\hline Variable & Parameter & $\begin{array}{l}\text { Demand Equation } \\
\text { (Eq. 7) }\end{array}$ & $\begin{array}{l}\text { Supply Equation } \\
\text { (Eq. 8) }\end{array}$ \\
\hline Intercept & & $168.40(1.51)$ & $66.11(0.50)$ \\
\hline Ln(Price of beer/barrel) & $\ln P^{t}$ & $-67.92(-4.77)^{\star * *}$ & \\
\hline Ln(Price Index of Spirits) & lnPrice Spirits $^{\text {S }}$ & $56.97(2.60)^{\star \star}$ & \\
\hline Ln(Price Index of Carb. Drinks) & InPrice Cola $^{\text {Co }}$ & $6.08(0.37)$ & \\
\hline Ln(Disposable Inc. per Capita) & $\ln \operatorname{Inc} c_{t}$ & $0.91(0.06)$ & \\
\hline Payroll Price/ barrel & $w_{t}^{L}$ & & $-8.07(-0.79)$ \\
\hline Materials Price/ barrel & $w_{t}^{L}$ & & $-0.67(-0.40)$ \\
\hline (Mat. Price/barrel ${ }^{*}$ Payroll price/barrel) $)^{\frac{1}{2}}$ & $\left(\begin{array}{ll}w_{t}^{L} & w_{t}^{L}\end{array}\right)^{\frac{1}{2}}$ & & $4.44(0.55)$ \\
\hline Real Capital Stock & $K_{T}$ & & $-0.001(-1.26)$ \\
\hline Federal Tax/barrel & $\operatorname{tax}_{t}^{\text {fed }}$ & & $13.0(3.70)^{\star *}$ \\
\hline Market Power Parameter & $\omega$ & & $0.08(0.13)$ \\
\hline$R^{2}$ & & 0.83 & 0.68 \\
\hline
\end{tabular}

Note: (i) ${ }^{\star * \star}$ Indicates significance at $99 \%$; ${ }^{\star \star}$ Indicates significance at 95\%; (ii) t-statistics in parentheses.

\section{APPENDICES: VARIABLES AND MODEL ESTIMATION DETAILS}

\section{Appendix Table 1: Model variables in SAS}

\begin{tabular}{ll}
\hline Variables in equations $(\mathbf{7})$ and $(8)$ & Corresponding variables in the SAS program \\
\hline$Q_{t}$ & QUANTITY \\
\hline$P_{t}$ & PRICE_BARREL_1984 \\
\hline Price $^{\text {Spirit }}$ & SPIRITS_PRICE_INDEX_1984 \\
\hline Price $^{\text {Cola }}$ & CARB_DRINK_PRICE_INDEX_1984 \\
\hline$I n c_{t}$ & DISINC_PER_CAPITA_1984 \\
\hline$w_{t}^{L}$ & PAYROLL_BARREL_1984 \\
\hline$w_{t}^{M}$ & MAT_BARREL_1984 \\
\hline$K_{t}$ & REAL_CAPTIAL_STOCK_1984 \\
\hline tax $_{t}^{\text {fed }}$ & FTAX_1984
\end{tabular}

\section{Appendix Table 2: SAS program (SAS 9.4 used)}

(i) Estimation of the U.S. Brewing industry NEIO model: SAS codes

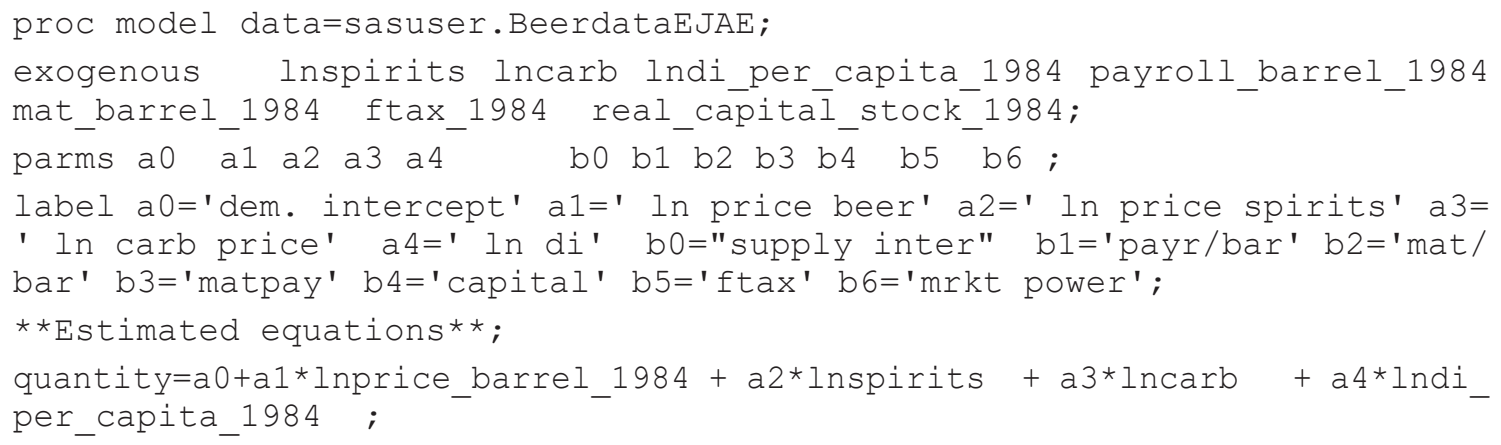




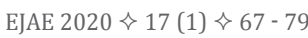

BHUYAN, S. $\diamond$ IS THERE MARKET POWER IN THE U.S. BREWING INDUSTRY?

price barrel $1984=$ b0 +b1*payroll_barrel_1984 + b2*mat barrel $1984+$

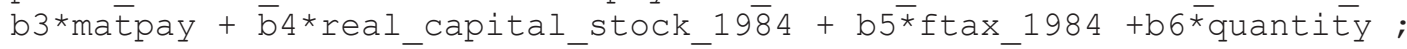

fit quantity price_barrel_1984 / 3sls hausman ;

instruments a2 a3 a4 b1 b2 b3 b4 b5 ;

run;

\section{Appendix Table 3: Data file}

(ii) Log transformation of variables

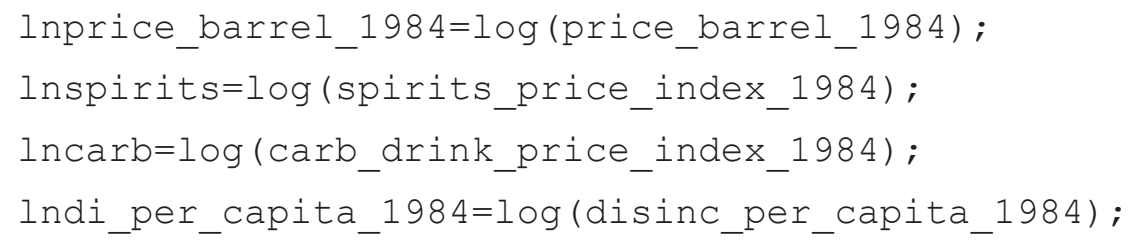




\section{POSTOJI LI TRŽIŠNA MOĆ U OKVIRIMA AMERIČKE INDUSTRIJE PIVA?}

\section{Rezime:}

Uvećana konsolidacija $u$ industriji piva SAD-a, s pravom je dovela do brige u vezi sa sposobnošću činilaca te industrije da iskažu tržišnu moć u odnosu na naftnu industriju. Zasnivajući se na strukturalnom modelu oligopolskog ponašanja, ovo istraživanje analizira tržišnu moć industrije piva u SAD-u, tokom perioda od 30 godina, tokom kojeg je ovaj sektor iskusio ubrzan porast - kada je u pitanju koncentracija i gašenje nemalog broja malih firmi. Rezultati pokazuju da je tržište piva osetljivo na cene, kao i da je pivo zamenilo i žestoka pića i gazirana, bezalkoholna pića. Premda nismo mogli da utvrdimo uticaj vrednosti radne snage i materijala na cenu piva, utvrdili smo da je federalni porez na pivo uvećao cenu istog. Naši rezultati ukazuju na to da - iako postoji naznaka tržišne moći, američka industrija piva nije uspela da emituje oligopolsku moć u odnosu na naftnu industriju (distributere i preprodavce).

\section{Ključne reči:}

američka industrija piva, tržišna moć, NEIO (novi međunarodni ekonomski poredak).

\section{JEL classification:}

L13, D43 